\title{
Pediococcus ethanolidurans sp. nov., isolated from the walls of a distilled-spirit-fermenting cellar
}

Correspondence
Xiuzhu Dong
dongxz@sun.im.ac.cn
The pediococci are a group of lactic acid bacteria with spherical cells that are typically arranged in tetrads (Garvie, 1986). Traditionally, they have been used in the fermentation of vegetables and meats and as additives for animal feeds (Knorr, 1998; Tannock, 1997). To date, the genus Pediococcus contains nine recognized species: Pediococcus damnosus, $P$. acidilactici, $P$. pentosaceus, $P$. parvulus, $P$. inopinatus, P. dextrinicus, P. claussenii (Dobson et al., 2002), P. cellicola (Zhang et al., 2005) and P. stilesii (Franz et al., 2006) (two other species have been reclassified as Tetragenococcus halophilus and Aerococcus urinaeequi). Most of the species were isolated from fermenting vegetables and beer; $P$. cellicola was the only one isolated from a distilled-spirit-fermenting cellar in China.

Chinese liquors are produced by a solidified grain fermentation and have special fragrances as a result of fermentation by a diverse microbial flora. As lactic acid bacteria were believed to produce aromatic substances during lactic acid fermentation, in this work, these microorganisms were surveyed on behalf of Chinese wine breweries. Among the lactic acid bacteria isolated, several ethanol-tolerant Pediococcus strains were obtained, including the novel species $P$. cellicola (Zhang et al., 2005). In the

The GenBank/EMBL/DDBJ accession numbers for the 16S rRNA gene sequences of strains Z-9 ${ }^{\top}$ and Z-17 are AY956789 and DQ400914, respectively. present study, we isolated and characterized another two pediococcal strains from a brewery in Hebei Province, China. They exhibited distinct phenotypic characteristics, a divergent 16S rRNA gene sequence, and lower rates of DNA-DNA hybridization. All of these characteristics distinguish them from existing Pediococcus species, including P. cellicola.

P. damnosus LMG $11484^{\mathrm{T}}$, P. inopinatus LMG $11409^{\mathrm{T}}$ and $P$. parvulus LMG $11486^{\mathrm{T}}$ were kindly provided by the Laboratory of Microbiology, Ghent, Belgium; P. cellicola LMG $22956^{\mathrm{T}}$ was from our laboratory. Strains $\mathrm{Z}-9^{\mathrm{T}}$ and Z17 were originally isolated from the walls of a distilled-spiritfermenting cellar in Hebei Province, China. They were isolated and then purified by streaking the samples on MRS agar (De Man et al., 1960). The strains were routinely grown aerobically on the same medium at $37^{\circ} \mathrm{C}$ unless indicated otherwise. Determinations of the end products of glucose fermentation, the lactate isomers, catalase activity and other physiological and biochemical characteristics were carried out as described previously (Zhang et al., 2005).

Genomic DNA was extracted and purified as described by Marmur (1961). The 16S rRNA gene was amplified by means of a PCR using the genomic DNA as the template, and was sequenced using an ABI PRISM 377XL DNA sequencer. The 16S rRNA gene sequences of the most closely related species were retrieved from GenBank and then aligned; the similarity analysis was performed using the 
CLUSTAL_X program (Thompson et al., 1997). The distance matrix was calculated by using the Kimura distance formula implemented in the MEGA3 program (Kumar et al., 2004) and the PHYLIP package (Felsenstein, 1993); the global gap removal item was selected. A reduced phylogenetic tree was produced from trees constructed using the neighbourjoining (Saitou \& Nei, 1987), maximum-likelihood and maximum-parsimony methods. The stability of the tree clustering was evaluated by means of a bootstrap analysis of 1000 datasets. The DNA G + C content was determined by using the thermal denaturation method (Marmur \& Doty, 1962). DNA-DNA relatedness was determined on the basis of the DNA-DNA liquid reassociation rate (De Ley et al., 1970), using a DU-800 spectrophotometer (Beckman) with a thermal controller.

The cells of the two isolates were Gram-positive, non-sporeforming, non-motile cocci occurring in pairs or tetrads. Lactic acid $[\mathrm{D}(-)$ and $\mathrm{L}(+)$ isomers in the ratio $50: 50]$ was the sole product of glucose fermentation; gas was not produced. The strains grew as facultative anaerobes. Catalase activity was not present. These characteristics identified the two strains as members of the genus Pediococcus. Conventional methods and the API $50 \mathrm{CH}$ system showed that the two strains could use several monosaccharides and disaccharides as sole carbon and energy sources (see Table 1 and the species description). The fermentation of rhamnose, lactose and D-turanose was variable between the two strains. The mean generation time of the two strains was $3 \cdot 15 \pm 0 \cdot 15 \mathrm{~h}$ when they were cultured aerobically. In addition, strain Z-9 $9^{\mathrm{T}}$ and strain Z-17 were able to tolerate 7 and $6.5 \%$ ethanol $(\mathrm{v} / \mathrm{v})$, respectively, this being consistent with their natural niche habitat.

The complete 16S rRNA gene sequences of strain Z-9 ${ }^{\mathrm{T}}$ and Z-17 were compared with those of Pediococcus species retrieved from GenBank. A reduced phylogenetic tree rooted with Bacillus subtilis NCDO $1769^{\mathrm{T}}$ was constructed using the neighbour-joining, maximum-likelihood and maximum-parsimony methods (Fig. 1). The novel strains clustered in the $P$. damnosus $-P$. inopinatus $-P$. parvulus $-P$. cellicola group, showing $16 \mathrm{~S}$ rRNA gene sequence similarities ranging from $98 \cdot 3$ to $98 \cdot 7 \%$.

The mean genomic DNAG + C content of the two novel strains was $39 \cdot 5 \pm 0 \cdot 5 \mathrm{~mol} \%$ ( $39 \mathrm{~mol} \%$ for type strain Z $-9^{\mathrm{T}}$ ), which was within the range for the genus Pediococcus (34-42 mol\%). The level of DNA-DNA hybridization between strains Z-9 ${ }^{\mathrm{T}}$ and Z-17 was $87 \cdot 5 \%$, while those between strain Z- $9^{\mathrm{T}}$ and $P$. damnosus LMG $11484^{\mathrm{T}}$, P. inopinatus LMG $11409^{\mathrm{T}}$, P.parvulus LMG $11486^{\mathrm{T}}$ and P. cellicola LMG $22956^{\mathrm{T}}$ were $14 \cdot 6,33,28 \cdot 7$ and $16 \cdot 8 \%$, respectively, i.e. below the DNA-DNA relatedness threshold $(70 \%)$ recommended for species delineation (Wayne et al., 1987).

Table 1. Differential phenotypic characteristics of strains $Z-9^{\top}$ and $Z-17$ and phylogenetically related species

Taxa: 1, strain Z-9 ${ }^{\mathrm{T}}$; 2, strain Z-17; 3, P. cellicola (Zhang et al., 2005); 4, P. damnosus (Back, 1978); 5, P. inopinatus (Back, 1978); 6, P. parvulus (Gunther \& White, 1961); 7, P. dextrinicus (Garvie, 1986). The data were also verified in this study by using conventional methods. +, Positive; -, negative; d, 50-89\% of strains positive; ND, no data available. Results of acid-production tests are indicated as: C, data obtained using conventional methods; API, data obtained using the API $50 \mathrm{CH}$ system; no symbol shown, both conventional methods and the API $50 \mathrm{CH}$ system were used.

\begin{tabular}{|c|c|c|c|c|c|c|c|}
\hline Characteristic & 1 & 2 & 3 & 4 & 5 & 6 & 7 \\
\hline Arabinose & $+(\mathrm{C}),-(\mathrm{API})$ & - & + & $-(\mathrm{C})$ & $-(\mathrm{C})$ & $-(\mathrm{C})$ & $-(\mathrm{C})$ \\
\hline Xylose & - & $+(\mathrm{C}),-(\mathrm{API})$ & + & $-(\mathrm{C})$ & $-(\mathrm{C})$ & $-(\mathrm{C})$ & $-(\mathrm{C})$ \\
\hline Rhamnose & + & - & + & $-(\mathrm{C})$ & $-(\mathrm{C})$ & $-(\mathrm{C})$ & $-(\mathrm{C})$ \\
\hline Lactose & + & - & + & $-(\mathrm{C})$ & $+(\mathrm{C})$ & $-(\mathrm{C})$ & $\mathrm{d}(\mathrm{C})$ \\
\hline 2-Ketogluconate & - & - & + & ND & ND & ND & ND \\
\hline Amygdalin & + & + & - & $\mathrm{ND}$ & $\mathrm{ND}$ & ND & $\mathrm{ND}$ \\
\hline \multicolumn{8}{|l|}{ Growth at/in: } \\
\hline $\mathrm{pH} 3 \cdot 8$ & + & + & + & - & - & - & - \\
\hline $\mathrm{pH} 7 \cdot 5$ & + & + & + & - & + & + & + \\
\hline $30^{\circ} \mathrm{C}$ & + & + & + & - & + & + & + \\
\hline $6 \cdot 5 \%$ Ethanol $(\mathrm{v} / \mathrm{v})$ & + & + & + & + & - & - & - \\
\hline $7 \%$ Ethanol (v/v) & + & - & + & + & - & - & - \\
\hline $7 \cdot 5 \%$ Ethanol $(\mathrm{v} / \mathrm{v})$ & - & - & + & + & - & - & - \\
\hline
\end{tabular}




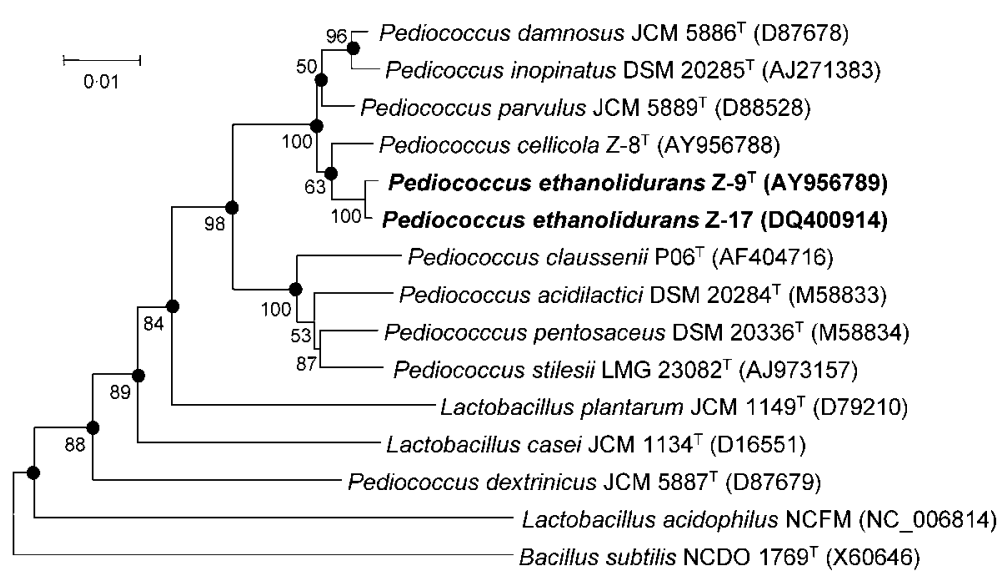

Fig. 1. Neighbour-joining phylogenetic dendrogram of strain $Z-9^{\top}$ and related lactic acid bacterial species based on 16S rRNA gene sequence similarity. The tree was rooted with $B$. subtilis NCDO $1769^{\top}$. Solid circles indicate coincident branches supported by trees constructed using the maximum-likelihood and maximum-parsimony methods. Numbers at branch points are levels of bootstrap support (\%) based on analysis of 1000 resampled datasets with the three methods. GenBank accession numbers are given in parentheses. Bar, $1 \%$ sequence divergence.
Strain Z-9 ${ }^{\mathrm{T}}$ showed higher levels of $16 \mathrm{~S}$ rRNA gene sequence similarity with $P$. damnosus LMG $11484^{\mathrm{T}}(98 \cdot 6 \%), P$. inopinatus LMG $11409^{\mathrm{T}}(98 \cdot 3 \%)$, P. parvulus LMG $11486^{\mathrm{T}}$ $(98 \cdot 3 \%)$ and P. cellicola LMG $22956^{\mathrm{T}}$ (98.5\%). However, low levels of DNA-DNA relatedness together with some phenotypic features distinguished strains Z-9 ${ }^{\mathrm{T}}$ and Z-17 from these Pediococcus species, thus confirming the two novel strains as representing a separate species. Strain Z-9 $9^{\mathrm{T}}$, strain Z-17 and $P$. cellicola were all isolated from a Chinese wine brewery, and they differed from $P$. damnosus, $P$. inopinatus and $P$. parvulus in having a higher growth temperature $\left(45^{\circ} \mathrm{C}\right)$, a tolerance of $6 \cdot 5-7 \cdot 5 \%$ ethanol and a lower final $\mathrm{pH}$ (3.8). However, strains $\mathrm{Z}-9^{\mathrm{T}}$ and Z-17 differed from $P$. cellicola in fermenting methyl $\alpha$-D-mannoside, 2-ketogluconate, ribose, $\mathrm{D}$-xylose, aesculin and amygdalin and having different tolerances for ethanol and $\mathrm{NaCl}$. The characteristics that differentiated the novel strains from phylogenetically close Pediococcus species are shown in Table 1.

Phylogenetic relationships were also analysed on the basis of partial $f t s Z$ gene sequence similarity (data not shown). Strain $Z-9^{\mathrm{T}}$ was again shown to cluster in the $P$. damnosus $-P$. inopinatus $-P$. parvulus $-P$. cellicola group, with $\mathrm{fts} Z$ gene similarities in the range $77 \cdot 7-89 \cdot 6 \%$; the similarity between strain Z-9 ${ }^{\mathrm{T}}$ and P. cellicola LMG $22956^{\mathrm{T}}$ (which were isolated from the same environment) was $85 \cdot 3 \%$, implying that the two species could be closely related.

On the basis of their phenotypic characteristics, phylogenetic relationships and levels of DNA-DNA relatedness, strains Z-9 ${ }^{\mathrm{T}}$ and Z-17 represent a novel species of the genus Pediococcus, for which the name Pediococcus ethanolidurans sp. nov. is proposed.

\section{Description of Pediococcus ethanolidurans sp. nov.}

Pediococcus ethanolidurans (e.tha.nol.i.dur'ans. N.L. n. ethanol, ethanolis ethanol; L. part. adj. durans insensible, resisting; N.L. part. adj. ethanolidurans ethanol-resisting).

Cells are Gram-positive, non-spore-forming, non-motile, spherical and $0 \cdot 7-1 \cdot 0 \mu \mathrm{m}$ in diameter after $24 \mathrm{~h}$ in MRS liquid under aerobic conditions at $37^{\circ} \mathrm{C}$. Cells occur in pairs or tetrads. Colonies are greyish white, low-convex, circular, entire, opaque and about $1 \mathrm{~mm}$ in diameter after $24 \mathrm{~h}$ cultivation on MRS plates at $37^{\circ} \mathrm{C}$. Catalase-negative. Facultatively anaerobic. Lactic acid $[\mathrm{D}(-)$ and $\mathrm{L}(+)$ isomers in the approx. ratio $50: 50]$, but not gas, is produced from glucose fermentation. Growth occurs at $15-45^{\circ} \mathrm{C}$, with optimum growth occurring at $32-34^{\circ} \mathrm{C}$. The optimum $\mathrm{pH}$ for growth is $6 \cdot 0-6 \cdot 8$ (range, $\mathrm{pH} 3 \cdot 5-8 \cdot 3$ ). Strains $\mathrm{Z}-9^{\mathrm{T}}$ and Z-17 can grow with $\mathrm{NaCl}$ at 7 and $6.5 \%$, respectively, but not with $4 \% \mathrm{NaCl}$. Aesculin is hydrolysed but arginine is not. Acid is produced from galactose, glucose, fructose, mannose, methyl $\alpha$-D-glucoside, $N$-acetylglucosamine, amygdalin, arbutin, aesculin, salicin, cellobiose, maltose, sucrose, trehalose, gentiobiose and D-tagatose. Acid is not produced from glycerol, erythritol, D-arabinose, L-arabinose, ribose, D-xylose, L-xylose, adonitol, methyl $\beta$-Dxyloside, sorbose, dulcitol, inositol, mannitol, sorbitol, methyl $\alpha$-D-mannoside, melibiose, inulin, melezitose, raffinose, starch, glycogen, xylitol, D-lyxose, D-fucose, Lfucose, D-arabitol, L-arabitol, gluconate, 2-ketogluconate or 5-ketogluconate. Strain Z-9 ${ }^{\mathrm{T}}$ ferments rhamnose and lactose but not D-turanose, whereas strain Z-17 is the reverse of this. The mean genomic DNA G $+C$ content is $39 \cdot 5 \pm 0 \cdot 5 \mathrm{~mol} \%$ (39 mol\% for strain $\mathrm{Z}-9^{\mathrm{T}}$ ).

The type strain, Z-9 $9^{\mathrm{T}}\left(=\mathrm{AS} 1.3889^{\mathrm{T}}=\mathrm{LMG} 23354^{\mathrm{T}}\right.$ ), was isolated from a distilled-spirit-fermenting cellar in Hebei Province, China.

\section{Acknowledgements}

This study was supported by a grant (no. 30230020) from the National Natural Science Foundation of China.

\section{References}

Back, W. (1978). Zur Taxonomie der Gattung Pediococcus. Phanotypische und genotypische Abgrenzung der bisher bekannten Arten sowie Beschtribung einer neuen bierschadlichen Art: Pediococcus inopinatus. Brauwissenschaft 31, 237-250, 312-320 (in German). 
De Ley, J., Cattoir, H. \& Reynaerts, A. (1970). The quantitative measurement of DNA hybridization from renaturation rates. Eur $J$ Biochem 12, 133-142.

De Man, J. C., Rogosa, M. \& Sharpe, M. E. (1960). A medium for the cultivation of lactobacilli. J Appl Bacteriol 23, 130-135.

Dobson, C. M., Deneer, H., Lee, S., Hemmingsen, S., Glaze, S. \& Ziola, B. (2002). Phylogenetic analysis of the genus Pediococcus, including Pediococcus claussenii sp. nov., a novel lactic acid bacterium isolated from beer. Int J Syst Evol Microbiol 52, 2003-2010.

Felsenstein, J. (1993). PHYLIP (Phylogeny inference package), version 3.5c. Distributed by the author. Department of Genome Sciences, University of Washington, Seattle, USA.

Franz, C. M., Vancanneyt, M., Vandemeulebroecke, K., De Wachter, M., Cleenwerck, I., Hoste, B., Schillinger, U., Holzepfel, W. H. \& Swings, J. (2006). Pediococcus stilesii sp. nov., isolated from maize grains. Int J Syst Evol Microbiol 56, 329-333.

Garvie, E. I. (1986). Genus Pediococcus Claussen 1903, 68 ${ }^{\mathrm{AL}}$. In Bergey's Manual of Systematic Bacteriology, vol. 2, pp. 1075-1079. Edited by P. H. A. Sneath, N. S. Mair, M. E. Sharpe \& J. G. Holt. Baltimore: Williams \& Wilkins.

Gunther, H. L. \& White, H. R. (1961). The cultural and physiological characters of the pediococci. J Gen Microbiol 26, 185-197.

Knorr, D. (1998). Technological aspects related to microorganisms in functional foods. Trends Food Sci Technol 9, 295-306.
Kumar, H., Tamura, K. \& Nei, M. (2004). MEGA3: integrated software for molecular evolutionary genetics analysis and sequence alignment. Brief Bioinform 5, 150-163.

Marmur, J. (1961). A procedure for the isolation of deoxyribonucleic acid from microorganisms. J Mol Biol 3, 208-218.

Marmur, J. \& Doty, P. (1962). Determination of the base composition of deoxyribonucleic acid from its thermal denaturation temperature. J Mol Biol 5, 109-118.

Saitou, N. \& Nei, M. (1987). The neighbor-joining method: a new method for reconstructing phylogenetic trees. Mol Biol Evol 4, 406-425.

Tannock, G. W. (1997). Probiotic properties of lactic-acid bacteria: plenty of scope for fundamental R \& D. Trends Biotechnol 15, 270-274.

Thompson, J. D., Gibson, T. J., Plewniak, F., Jeanmougin, F. \& Higgins, D. G. (1997). The CLUSTAL_X windows interface: flexible strategies for multiple sequence alignment aided by quality analysis tools. Nucleic Acids Res 25, 4876-4882.

Wayne, L. G., Brenner, D. J., Colwell, R. R. \& 9 other authors (1987). International Committee on Systematic Bacteriology. Report of the ad hoc committee on reconciliation of approaches to bacterial systematics. Int J Syst Bacteriol 37, 463-464.

Zhang, B., Tong, H. C. \& Dong, X. Z. (2005). Pediococcus cellicola sp. nov., a novel lactic acid coccus isolated from a distilled-spiritfermenting cellar. Int J Syst Evol Microbiol 55, 2167-2170. 